\section{The social psychological status of reward ${ }^{1}$}

WILLIAM H. MELSON, BOBBY J. variables suggested by two of these studies. CALDER, and CHESTER A. INSKO, Carismith, Collins, \& Helnreich (1966) University of North Carolina, Chapel Hill, found that a nonymous-written N.C. 27514

Two experiments investigated the effect of reward on forced compliance attitude change in relation to two supposedly crucial interactive variables. The results of these experiments indicated that previous analyses of these effects are open to serious question.

Psychology has long focused on the effects of reward. Social psychology has contributed to this work by exploring the effects of reward in creating such cognitive states as dissonance or regret. Dissonance (Festinger, 1957) is a state of psychological tension arising when a person has two cognitions such that the obverse of one follows from the other. Hence, in a counte rattitudinal role-playing situation (cf. Insko, 1967, pp. 219-244), dissonance theory predicts that an individual arguing for a point of view that he really does not believe in will reduce his resulting dissonance by changing his beliefs to be more consistent with his behavior. Reward is one of the reasons a person might engage in counterattitudinal role-playing. If such inconsistent behavior is induced by reward, then the greater the reward, the less the dissonance. A high reward produces more inconsistency than a low reward. Thus, according to dissonance theory, attitude change following counterattitudinal role-playing varies as an inverse function of the amount of reward offered. Reinforcement theory, on the other hand, predicts a direct relation between attitude change and reward.

The experimental literature on this controversy has not been consistent. Festinger \& Carlsmith (1959) found that Ss who engaged in counterattitudinal role-playing for $\$ 1.00$ manifested more attitude change than $S s$ who performed for $\$ 20.00$. Other studies have likewise found an inverse relation (Cohen, 1962; Helmreich \& Collins, 1968; Kelman, 1953). But a sizable number of studies have also found a direct relation between attitude change and reward in the counterattitudinal role-playing situation (Elms \& Janis, 1965 ; Gerard, 1967; Helmreich \& Collins, 1968; Leventhal, 1964; Rosenberg, 1965).

Several recent studies, however, conducted by the University radio station seemingly establish the importance of "to help determine student feeling about the crucial interactive variables in reconciling matter" for a future special radio program. both dissonance and reinforcement theory Considering their surroundings in the results. The present study examines RTVMP Department, it is not surprising that
Ss seemed to find this story completely plausible. At this point, the anonymous-written Ss were asked to write an essay favoring the tuition increase. These Ss were further told that their exact words would not be used on the radio, but rather, writers would "merely extract the ideas they decide to use from various essays." Alternatively, public-oral Ss were asked to tape record statements favoring the tuition increase. The $E$, in the Ss' presence, recorded their statements while they were being made. These Ss were told that excerpts from their actual statements would be used on the broadcast. The E, finally, informed the Ss that they would receive payment $(\$ .50$ or $\$ 2.50$ ). When announcing this payment to the choice Ss, the E again stressed that their participation was entirely voluntary and that they would receive credit anyway. The payment was mentioned to the no-choice $S s$ almost as an afterthought.

After finishing the essay or oral statement, Ss evaluated a "substantial tuition increase" on eight 7-point semantic-differential scales and gave an overall reaction on a 7 -point scale asking how justified such an increase would be. A second questionnaire assessed the $\mathrm{Ss}^{\prime}$ perceived freedom not to participate. A postexperimental interview then took place in which the $E$ made sure that the $S$ had understood the task and was not suspicious. The $\mathbf{E}$ also asked about the Ss' reactions to the monetary payment and these were later categorized as favorable or unfavorable (two judges showed $98.21 \%$ perfect agreement). Lastly, the essays and oral statements were coded (two judges showed $95.54 \%$ perfect agreement) along a dimension of strict commitment to favoring the increase.

Results and Discussion

The experimental situation evidenced a high degree of realism-so much so that we experienced minor difficulty in debriefing Ss. Also, according to the postexperimental checks, the experimental manipulations were successful. Ss' ratings of the amount of choice they had felt (perceived choice scores) and the number of Ss giving favorable reactions to the reward are contained in Table 1. The differences in perceived-choice and no-choice groups is significant in the predicted direction by one-tailed $t$ test $(t=1.72, p<.05$ with $111 \mathrm{df}$ ). Significantly more Ss in the $\$ 2.50$ condition reacted favorably to the money than in the $\$ .50$ condition $\left(x^{2}=9.46\right.$, $p<.01$ with $1 \mathrm{df}$ ). All other effects for these scores were nonsignificant. It appears that the experimental procedures did, in fact, create the theoretically intended conditions.

Table 1 gives the mean attitude (semantic-differential ratings) and justification scores. The mean attitude in the 
Table 1

Assessments of Various Reactions in the Eight Experimental Conditions

\begin{tabular}{|c|c|c|c|c|c|c|c|c|}
\hline & \multicolumn{4}{|c|}{$\begin{array}{l}\text { Written-Anonymous } \\
\text { (Before-Writing) }\end{array}$} & \multicolumn{4}{|c|}{$\begin{array}{c}\text { Public-Oral } \\
\text { (After-Writing) }\end{array}$} \\
\hline & \multicolumn{2}{|c|}{ No-Choice } & \multicolumn{2}{|c|}{ Choice } & \multicolumn{2}{|c|}{ No-Choice } & \multicolumn{2}{|c|}{ Choice } \\
\hline & $\$ .50$ & $\begin{array}{r}\$ 2.50 \\
(\$ 5.00) \\
\end{array}$ & $\$ .50$ & $\begin{array}{c}\$ 2.50 \\
(\$ 5.00)\end{array}$ & $\$ .50$ & $\begin{array}{r}\$ 2.50 \\
(\$ 5.00)\end{array}$ & $\$ .50$ & $\begin{array}{r}\$ 2.50 \\
(\$ 5.00) \\
\end{array}$ \\
\hline \multicolumn{9}{|c|}{ Experiment 1} \\
\hline Number of.Ss & 15 & 14 & 14 & 14 & 14 & 14 & 13 & 14 \\
\hline Perceived Choice $^{2}$ & 4.79 & 4.43 & 4.33 & 3.29 & 4.15 & 4.50 & 3.64 & 3.57 \\
\hline Favorability to Money ${ }^{3}$ & 4 & 11 & 4 & 9 & 6 & 10 & 3 & 11 \\
\hline Attitude 2 & 29.86 & 33.14 & 26.20 & 28.43 & 27.62 & 29.00 & 27.72 & 27.93 \\
\hline Justification 2 & 4.14 & 4.43 & 3.80 & 4.07 & 4.31 & 4.00 & 4.14 & 3.86 \\
\hline \multicolumn{9}{|c|}{ Experiment 2} \\
\hline Perceived Choice $^{2}$ & 5.79 & 7.29 & 4.50 & 5.50 & 7.00 & 7.29 & 3.57 & 4.21 \\
\hline Money Evaluation 2 & 5.57 & 6.36 & 4.64 & 5.57 & 4.86 & 5.57 & 5.14 & 5.36 \\
\hline Attitude 2 & 36.50 & 34.71 & 34.07 & 34.79 & 32.59 & 33.79 & 33.21 & 31.71 \\
\hline
\end{tabular}

1 Parentheses indicate that the name applies to Experiment 2.

2 Low numbers indicate high perceived choice and favorable (attitude and justification) reactions to increased tuition and money.

3 Number of Ss indicating a favorable reaction to the money.

control condition is 38.64 . This control mean differs significantly from the overall attitude mean $(\mathrm{t}=3.35, \mathrm{p}<.01$ with $124 \mathrm{df}$ ) and is higher than all eight of these experimental means. Eighty-one per cent of the experimental Ss had lower scores than the control group mean. The mean justification score in the control condition is 4.94. This mean differs significantly from the overall experimental mean $(t=2.24$, $p<.05$ with $124 \mathrm{df}$ ) and is higher than all eight of the experimental cells. Seventy-one per cent of the experimental Ss had justification scores below the control group mean. Thus, we have some evidence that counterattitudinal role-playing produced attitude change.

The effects of reward, choice, and mode of counterattitudinal role-playing will now be considered. Unweighted means analyses of variance were performed on the attitude and justification scores. Of the $14 \mathrm{Fs}$ generated, only 2 are greater than 1 . None are significant. In an attempt to understand this lack of effects, further analyses were undertaken. The data were partitioned according to whether Ss had participated in experiments before (naivete), according to favorable-unfavorable reaction to money, according to high and low perceived choice, and according to high and low commitment to the tuition increase. Unweighted means analyses of variance using these post hoc groups revealed no effects for reward, choice, or mode of counterattitudinal role-playing. Thus, this experiment does not substantiate the published experiments cited earlier which ostensibly relate the effects of reward to an interaction with choice and mode of counterattitudinal role-playing.

\section{EXPERIMENT 2}

The results of the first experiment are clear; the manipulated variables had no effect on attitudes. However, since the negative results of one study are not generally considered as important as the positive results of another study, we felt obliged to make another attempt. The lack of effects in the first experiment could be due to poor experimentation, or chance. Of course, the theory could be wrong, too. In view of the importance of the problem, another experiment was obviously called for. Consequently, we undertook to strengthen the following possible weaknesses in the first experiment. First, the choice manipulation may not have been strong enough. Second, the relative strengths of the very realistic counterattitudinal setting and the less realistic choice manipulation may have worked against the dissonance effect. Third, the fact that the $S s$ engaged in counterattitudinal role-playing may have counteracted any dissonance. [Rosenberg (1965, 1966) has argued that dissonance applies most unambiguously to situations in which counterattitudinal arguments are not actually elaborated. $\mathrm{He}$, in fact, interprets Carlsmith et al as being consistent with this hypothesis.] Fourth, the monetary incentive in the high-reward condition may not have been high enough.

$$
\text { Method }
$$

The second experiment was specifically designed to handle the above objections. The instructions were changed so as to further emphasize the choice manipulations. Choice Ss had to vocalize their willingness to continue with the task. The counterattitudinal task itself was modified by having all Ss write essays and by telling them that their essays were to be used as background material to aid writers in preparing a radio program concerning the proposed tuition increase. The written-anonymous vs public-oral manipulation was replaced by a manipulation as to when attitude toward the increase was assessed, before or after writing the counterattitudinal essay. Finally, the monetary incentive in the high-reward condition was increased from $\$ 2.50$ to $\$ 5.00$. The second experiment can thus be interpreted as a further at tempt to factorially combine the Linder, Cooper, and Jones and the Carlsmith, Collins, and Helmreich experiments. This time, however, the written-anonymous vs public-oral manipulation is viewed as a manipulation of the extensiveness of the counterattitudinal role-playing.

The attitude issue and $S$ recruitment method was the same as in the first experiment. Out of 141 Ss, 15 were eliminated, leaving 14 in each of the eight experimental cells and a control group. As already noted, three independent variables were manipulated: reward ( $\$ .50$ vs $\$ 5.00$ ), choice (choice vs no-choice), and position of attitude assessment (before vs after writing the essay). Except for the above modifications, the experimental procedure exactly paralleled Experiment 1 . The dependent variable assessments were also the same, with the two following minor changes: the justification measure was not included, and a 7-point scale for rating the appropriateness of the reward was included.

\section{Results}

The perceived choice and money scores are contained in Table 1 . An analysis of variance of the perceived choice scores revealed a significant main effect for the choice factor $(F=17.57, p<.01$ with 1 and $104 \mathrm{df}$ ). Judging from this assessment, our stated purpose of increasing the potency of the choice manipulation was definitely achieved. Also, an analysis of variance of the money evaluation question produced a significant reward effect $(F=7.42, p<.01$ with 1 and $104 \mathrm{df}$ ). No other effects in these analyses were significant.

Mean attitude scores are presented in Table 1. The mean for the control group is 37.50. Unlike the first experiment, this control mean does not differ significantly from the overall mean $(t=.42$, with $124 \mathrm{df})$. Apparently, we suceeded in our intention of reducing the effects of counterattitudinal role-playing itself.

An analysis of variance of the attitude scores did not yield a single significant effect. Accordingly, we again undertook extensive internal analyses of the data. Exact least-squares analyses of variance on the same partitions of the data used before again produced no significant results. Within-cell correlations were similarly unenlightening. In short, the analyses of the attitude scores seem to strongly replicate the results of Experiment 1. 


\section{Discussion}

As far as we can judge, the second experiment differed from the first in all the intended ways. In spite of the robustness of our experimental manipulations, we were still unable to obtain the theoretically predicted results. We consider this a serious state of affairs. How are we to account for our results and, indeed, the whole tradition of conflicting results in this area of the social psychology of reward?

Many social psychologists seem to explain this pattern of inconsistent results along the lines of Brehm's (1965, p. 64) notion that "the person best equipped to disprove a dissonance hypothesis is one who has been successful in supporting it." According to Brehm, this is because such a person is more likely to design a test "in a sensitive and adequate way." Or as Linder (1968, p. 121) puts it, "the important requirement is that the experimenter has the ability to create the conditions necessary to test his hypothesis." Aronson \& Carlsmith (1968, p. 21) advance essentially the same argument: "negative results are easily produced by incompetence. ... If an effect cannot be obtained, it may be that the effect does not exist or it may be the experimenter is not skillful enough to obtain it."

Now, it is certainly true that Es may be inexpert and insensitive. And it may be true that the present Es are a case in point. However, we did in fact follow the reported procedures of dissonance experiments as closely as possible; we even consulted with such researchers on both major and minor details. Our failure to obtain these effects convinces us not necessarily that dissonance theory is untrue, but rather that dissonance people are unable to specify the variables that will reliably produce dissonance results. We furthermore do not feel that psychology can afford to substitute commitment to a given theory for a rigorous specification of its variables. And, although they have not necessarily taken the same position regarding insensitive $\mathrm{Es}$, our conclusion seems to hold equally well for the reinforcement approach to attitude change. The social psychological status of reward in the counterattitudinal role-playing situation remains very much in doubt.

\section{REFERENCES}

ARONSON, E., \& CARLSMITH, J. M. Experimentation in social psychology. In G. Lindzey and E. Aronson (Eds.), Handbook of social psychology. Vol. 2. Reading, Mass.: Addison-Wesley, 1968. Pp. 1-79.

BREHM, J. W. Comment on "counter-norm at titudes induced by consonant versus dissonant conditions or role-playing." Journal of Experimental Research in Personality, 1965, 1, 61-64.

CARLSMITH, J. M., COLLINS, B. E., \& HELMREICH, R. L. Studies in forced compliance: I. The effect of pressure for compliance on attitude change produced by face-to-face role playing and anonymous essay writing. Joumal of Personality \& Social Psychology, 1966, 4, 1-13.

COHEN, A. R. An experiment on small rewards for discrepant compliance and attitude change. In J. W. Brehm and A. R. Cohen (Eds.), Explorations in cognitive dissonance. New York: Wiley, 1962. Pp. 73-78.

ELMS, A. C., \& JANIS, I. L. Counter-norm attitudes induced by consonant versus dissonant conditions of role-playing. Journal of Experimental Research in Personality, 1965, 1, 50-60.

FESTINGER, L. A theory of cognitive dissonance.
Evanston, Ill.: Row, Peterson, 1957.

FESTINGER, L., \& CARLSMITH, J. Cognitive consequences of forced compliance. Journal of Abnormal \& Social Psychology, 1959, 58, 203-210.

GERARD, H. B. Compliance, expectation of reward, and opinion change. Journal of Personality \& Social Psychology, 1967, 6, 360-364.

HELMREICH, R., \& COLLINS, B. E. Studies in forced compliance: Commitment and magnitude of inducement to comply as determinants of opinion change. Journal of Personality \& Social Psychology, 1968, 10, 75-81.

INSKO, C. A. Theories of attitude change. New York: Appleton-Century-Crofts, 1967.

KELMAN, H. C. Attitude change as a function of response restriction. Human Relations, 1953, 6 , 185-214.

LEVENTHAL, G. S. Reward magnitude, task attractiveness, and liking for instrumental activity. Journal of Abnormal \& Social Psychology, 1964, 68, 460-463.

LINDER, D. E. Experimenter behavior. Contemporary Psychology, 1968, 13, 120-121.

LINDER, D. E., COOPER, J., \& JONES, E. E. Decision freedom as a de terminant of the role of incentive magnitude in attitude change. Journal of Personality \& Social Psychology, 1967, 6, 245-254.

ROSENBERG, M. J. When dissonance fails: On eliminating evaluation apprehension from attitude measurement. Journal of Personality \& Social Psychology, 1965, 1, 28-42.

ROSENBERG, M. J. Some limits of dissonance: Toward a differentiated view of counterattitudinal performance. In $S$. Feldman (Ed.), The consistency postulate in social attitudes and behavior. New York: Academic Press, 1966.Pp. 137-170.

NOTE

1. A more detailed report of the experimental instructions and the statistical analyses can be obtained from the authors. 